\title{
Para una arqueología de la consciencia: La cardinalidad de la música en María Zambrano
}

\section{For an Archaeology of Consciousness: The Cardinality of Music in María Zambrano's Work}

Gabriel Gálvez Silva

Facultad de Humanidades, Departamento de Música

Universidad de La Serena, Chile.

ggalvez@userena.cl

\section{Resumen}

Nuestro trabajo es un estudio teórico cuyo objetivo es iluminar el rol paradigmático o cardinal de la música al interior de la obra de María Zambrano, proponiendo su solidaridad respecto del estado primordial de consciencia al que ella misma conduce. Consideraremos la metarritmisis sobrellevada por el discurso de la filósofa en cuanto progresivo descubrimiento de tal solidaridad, deteniéndonos en cómo Zambrano ejemplifica esta metamorfosis mediante el padecimiento de Antígona.

Palabras clave: María Zambrano, música, aurora, consciencia, Antígona.

\section{Abstract:}

Our work is a theoretical study aimed at explaining the paradigmatic or cardinal role of music within María Zambrano's work, proposing its solidarity with the state of primordial consciousness to which it leads. We will consider the metarritmisis of the philosopher's discourse as the progressive discovery of such solidarity, examining how Zambrano exposes this metamorphosis through Antigone's suffering.

Keywords: María Zambrano, music, dawn, consciousness, Antigone. 
Ahora no luce ya el Sol, y comienza a estar claro, tan claro.

La tumba de Antígona, María Zambrano

\section{A modo de introducción: El cardus para una metarritmisis}

Si adjetivamos como 'cardinal' y no como 'fundamental,' 'central' o 'axial' la condición que posee la música al interior de la obra de María Zambrano, es porque no solo aspiramos a señalar una sustancial importancia, sino que, sobre todo, a poner de manifiesto su porqué: la música opera como 'norte' del discurso filosófico zambraniano, orientándolo. En cierta manera, esta afirmación equivale a observar que, para Zambrano, la música es paradigma de comunicación de lo racionalmente incomunicable. Si logra parecerse a la música o, mejor aún, recuperar aunque sea algo de "la música inicial de lo indecible" (Claros del bosque 198), el discurso zambraniano, hacia su madurez, consigue su propósito no de cabalmente decir, ni siquiera de sugerir, sino de hacer sentir lo que de cualquier otro modo resulta incognoscible. Para Isabel Balza se trata de un ejercicio que asume el riesgo de no poder dar cuenta de lo que se quiere enseñar, que es aquello que ha sido "revelado" o, mejor aún -para nosotros-, oído. Por esto es que en la musicalidad, transferida metodológicamente a la escritura, es donde radica lo más fidedigno de la experiencia junto a la posible efectividad de las palabras:

La escritura es una apuesta porque en ella será posible recuperar algo de lo innombrable y notar la huella de lo pasivo. Las palabras dadas en la revelación aparecen esbozadas en el texto, lo que se cifra por ejemplo en el uso del punto suspensivo. Lo dado como pasivo no puede transformarse en palabra activa, sino quedar como huella en la escritura. Queda de lo revelado su huella, traspasando la escritura al modo de una cadencia, porque la palabra en la que se cifraría la verdad se constituye como pérdida irremediable. Por ello mismo, el trabajo de escribir consistirá en testimoniar lo entrevisto o percibido en la revelación. La escritura se alza como recurso que recoge la cadencia y la huella de lo que queda más allá de un posible decir o escribir [...]. El aspecto musical que se consiga será prueba o síntoma de lo logrado de la tarea, puesto que la música de la palabra nombra en Zambrano esos elementos que distinguen al saber de oído y que ella trata de recuperar para su escritura-método (Balza 51-52).

Esta condición de la música en cuanto modelo del proyecto filosófico zambraniano, empero, es un fenómeno progresivo a lo largo de su desarrollo, aun cuando la prosa de nuestra autora se encuentre impregnada de musicalidad desde sus primeros escritos. Luego, podría decirse que la obra de Zambrano transita hacia su propia musicalidad por el cardus que la misma música paradigmáticamente indica y demarca. Y este tránsito es en el tiempo; una metamorfosis que, iniciándose en el exilio caribeño de la filósofa, alcanzará su expresión concluyente durante los años que pase en el Jura francés: todo 
un periodo dominado por la composición y la revisión de su obra capital, El hombre y lo divino (cuya primera edición es de 1955, publicándose en 1973 la revisada y aumentada), coronado por la escritura del definitivamente musical Claros del bosque (1977). Documenta Moreno Sanz a propósito de El hombre y lo divino y su historia:

De La Habana a La Pièce hemos de recomponer la genealogía completa de este central libro en sus dos nítidas fases (1946-1953 y 1969-1972) y el final punto de "fuga" hacia una razón musical que hallará sus irradiaciones en los últimos escritos de Zambrano y que explícitamente se expondrá como tal razón musical en Notas de un método. La Habana fue el lugar que propició este magnetismo irradiador que halló su confín en los claros del bosque de La Pièce (41).

La noción de "metamorfosis" la aporta la propia filósofa, valorándola como estado inmanente a la totalidad que lo humano integra, no obstante desatendido e invisibilizado por la construcción histórica - pretendidamente uniforme- de la racionalidad moderna. Escribe Zambrano en un artículo de 1985, precisamente titulado Metamorfosis:

Sucede entre la luz y el agua, onda que se despierta con un desconocido ritmo de la misma creación dentro, pues de su movimiento incesante y a pesar de tanta ciencia, desconocido. Onda y movimiento que puede quedar invisible para nuestra humana mirada, tan remotamente arrojada -desentrañada- de tantos paraísos, pues que el hombre este que somos quizá pudo no haber tenido necesidad de mirar dentro de alguno de sus perdidos paraísos. Invisible, pues, pudiera quedar aquella onda y movimiento, tan invisible como la creación misma, ya que la creación, ella, no ha tenido por qué seguir el orden único y sucesivo, tal como nos la presentan, a imagen y semejanza de la acción de un hombre de ahora, en su fábrica gigantesca, de la que pueden salir, y han salido, algunos productos. Mas la creación, ella, no es un producto, ni puede dar lugar a ninguna producción. Ella no es productora. No lo ha sido por tanto de este humano ser que se nos aparece fijado de una vez para siempre -a pesar de la teoría de la evolución- con una determinada forma y modo de moverse (Las palabras del regreso 115).

Es del todo necesario y significativo observar que Zambrano, una vez centrada en el acontecer humano, explica su noción de metamorfosis recurriendo a dos principios antecedentes. Por un lado, la experiencia iniciática o mística, precisamente referida como un "viaje":

Y así nos quedan algunos nombres de estas visitas y viajes -a los ínferos, al firmamento, y al más allá-: Orfeo y el filósofo de la caverna y otros raptados como Elías por su carro de fuego entrando así en espacios inaccesibles. Elías dejó su manto a su discípulo Eliseo para que pudiese atravesar el río que separa este lugar de lo visible -esta tierra de todos- de aquél ignoto espacio adonde él, Elías, fue arrebatado. Y el viaje de los chamanes, preparado iniciáticamente, 
es también evidente, así como parecen serlo los viajes de aquellos místicos de todas las religiones -fundadores algunos- que han padecido de éxtasis incontenibles. Y parece evidente que ningún de veras estático lo haya sido por su propia voluntad. Por el contrario, se conocen algunos tristísimos casos de seres que han usado de todas las disciplinas ascéticas sin conseguir ni el éxtasis, ni la visión que a otras simples criaturas se les ha dado (Las palabras del regreso 116).

Y por otro, el concepto de metarritmisis aportado por su admirado Miguel de Unamuno: Y sin llegar a la transfiguración, ni pasar por éxtasis alguno, Unamuno, el autor de El sentimiento trágico de la vida, se conformó con recurrir a la Metarrítmisis, a un fenómeno musical -cosa rara en él, que tan poco musical se nos figura. En uno de sus más pequeños ensayos, coleccionados en la edición de la Residencia de Estudiantes, expone con gran simplicidad y fluencia la metarrítmisis como el remedio que cambiaría la historia de España, la dura, impenetrable, obstinadamente reiterable historia de España (Las palabras del regreso 117-118).

Se refiere Zambrano al breve ensayo La juventud "intelectual” española, publicado por Unamuno en 1896 y cuyo inicio, justamente, consiste en una explicación del concepto aludido:

Hay en el griego alejandrino y en el moderno una hermosa palabra metarritmisis (que un portugués escribiría metarrhythmisis), que significa "cambio de ritmo" o sea trasmutación de íntima estructura. Se la halla empleada en el sentido de "reforma o trasformación" más o menos íntima, pero en la fuerza de su composición designa una trasformación la más íntima que en un ser cabe, puesto que es la de su ritmo, faz de su más honda estructura (Unamuno 369).

Con gran severidad arremete el bilbaíno en este escrito contra la superficialidad de la que irónicamente menciona como "juventud 'intelectual' española”, a la que acusa de ser "meramente literaria, es decir, meramente cómica, artística, científica, erudita" (374), inconsciente, en su autocomplacencia, de las que son sus propias dolencias espirituales, sintomáticamente manifiestas en "el horror a las ideas y la diarrea de palabras" (374). Ante el panorama ofrecido por aquellos que considera jóvenes intelectuales "libres, pero sin tierra espiritual, virgen y fecunda", agarrados regaladamente "del viejo campo tradicional, del que fue de sus tatarabuelos y es hoy de los amos que les explotan el espíritu" (376), Unamuno declara la necesidad urgente de una crisis, de una transformación, no en la superficie de la cultura, sino en las profundidades del ser humano que la protagoniza:

Es lo que necesita nuestra juventud intelectual, si es que aún hay para ella remedio: ser metarritmizada; una sacudida en las más íntimas y entrañables palpitaciones de su ser. Ni reforma ni revolución bastan. Necesita la conciencia colectiva de nuestro pueblo una crisis que produzca lo que en psicología patológica se llama 
cambio de personalidad; un derrumbarse el viejo "yo" para que se alce sobre sus ruinas y nutrido de ellas el "yo" nuevo, sobre la base de continuidad de las funciones sociales meramente fisiológicas.

Sí, necesitamos que una vibrante metarritmisis nos transpersonalice (370).

Cuando Zambrano publica Metamorfosis, el 16 de junio de 1985 en Diario 16, se encuentra ya viviendo los últimos años de su vida, de vuelta en su patria tras 45 años de exilio. De lo que en este escrito da cuenta no es una maravilla ajena, sino el proceso que ella misma ha vivido, y el que le interesa que España conozca. Por eso es tan importante, además de chamanes y místicos, la mención de Unamuno, sutilmente proclamando la filósofa que ella sí respondió al llamado del vasco, llevando a cabo, en su propio proyecto, la más profunda y genuina metarritmisis, que es la acorde al sentido musical de la palabra.

Esta 'metarritmización' del discurso zambraniano no puede, sin embargo, dejar de relacionarse a una ausencia del todo notable: la filósofa nunca recogió ni dispuso en un libro puntual los escritos que contienen sus reflexiones sobre la música, en contradicción su inmensa relevancia -aquella que hará a Zambrano preguntarse si acaso es el músico, y no el filósofo, el mismísimo "protagonista de la cultura de Occidente" (Notas de un método 99) - con el hecho de no ocupar un apartado específico, salvo escasos y brevísimos artículos. Se trata, entonces, la de la música, de una presencia que, tras ser hallada, se encuentra diseminada a lo largo de toda la obra zambraniana, al modo de las migas de pan que el Pulgarcito de Perrault esparce para orientarse en el bosque, de regreso a su hogar. Valga esta arbitraria comparación para el tema de fondo que nos interesa abordar aquí: el 'norte' que la música cardinalmente indica no es, en Zambrano, un topos por descubrir, sino uno al que volver.

\section{Exilio, catábasis e iniciación}

La inquietud por un retorno o por una recuperación de lo extraviado, siempre asociada a una queja en contra de las limitaciones de la consciencia, podría rastrearse desde los primeros escritos de la filósofa, en especial Nostalgia de la Tierra (1933), donde acusa: “ ¡Nostalgia de la más presente, de la que nunca nos falta! La tierra está ahí presente en su permanente cita. Pero la habíamos perdido. Camino adentro de la conciencia -terrible devoradora de realidades- se había, también, disuelto" ( $\mathrm{La}$ razón en la sombra 75-76).

Es, no obstante, comenzado el exilio y derruidas las circunstancias de la que hasta entonces había sido su vida, que Zambrano comienza poco a poco a situarse en la que, años después, afirmará como su "senda", la que ha de rubricar específicamente como "órfico-pitagórica" (De la Aurora 187), dando cuenta así tanto de su musicalidad como de su vocación recuperativa de lo pasado y perdido. Adquiere, 
entonces, el exilio mismo una órfica impronta de catábasis, tal como lo ha señalado el ensayista cubano Jorge Luis Arcos: "En cierto sentido, en 1939, cuando María Zambrano cruza la frontera de España hacia Francia, ya derrotada la República, comenzaba también una suerte de 'viaje iniciático', su 'descenso a los ínferos', su destino órfico" (639).

Este iniciático descenso a sus propios ínferos, diríase al rescate de la Eurídice que es su propia alma, Zambrano lo experimentará cabalmente durante sus años de estadía en el Caribe, especialmente en Cuba, donde arriba recién comenzado 1940 y desde donde partirá hacia Roma en junio de 1953. Efectivamente, los textos más relevantes de Zambrano durante este periodo poseen un carácter marcadamente confesional, dando cuenta del profundo autoexamen que su autora lleva a cabo, desde Confesiones de una desterrada (1940) hasta Sentido de la derrota (1953), pasando por Las catacumbas (1943) y la esencial serie de Delirios, encabezada por Delirio de Antígona (1948) y completada por Delirio y destino, escrito en La Habana durante 1952. La importancia de este proceso de autognosis solo puede calibrarse teniendo en cuenta que el gran producto de esta época es El hombre y lo divino, donde la senda órfico-pitagórica ya aparece como enteramente asumida, tal como lo demuestra "La condenación aristotélica de los pitagóricos", su capítulo medular.

Luego, el exilio constituye oportunidad para la inmersión de Zambrano en sus catacumbas internas. Se nos revela, entonces, el sorprendente isomorfismo entre la figura de la Zambrano exiliada y lo que esta, en su exilio, intenta recuperar; aquello que a partir de su propio yo proscrito se proyecta a todo lo que ha sufrido el mismo destino a manos del definitivo poder humano, que es el poder del raciocinio: la poesía, el alma, la piedad, el pitagorismo, la realidad misma respecto del universo meramente definido por la consciencia. Declara Zambrano a propósito de la empresa separatista y marginadora de la razón:

Y lo que iba quedándose fuera no eran cosas, sino nada menos que la realidad, la realidad oscura y múltiple. Al reducirse el conocimiento a la razón solamente, se redujo también eso tan sagrado que es el contacto inicial del hombre con la realidad a un modo único: el de la conciencia. Quedaba la conciencia en su claridad lunar aislada hasta el propio cuerpo, donde por no se sabe qué azarosa contingencia venía a estar insertada (El hombre y lo divino 191-192).

Y, siempre de manera misteriosamente concordante, el exilio, donde Zambrano desarrolla su filosofía de lo exiliado, es iniciáticamente padecido por la filósofa en un contexto necesaria y absolutamente marginal respecto de las capitales de Occidente; es debido a su insular primitivismo que el Caribe resulta decisivo para que la filósofa emprenda su indagación anímico arqueológica, aportando vivencialmente a su descubrimiento de lo sagrado en cuanto objeto de la primordial experiencia humana, aquella que Zambrano tantas veces mencionará como el relegado "sentir originario" (Notas de un método 99). Indica Arcos, esta vez en su estudio preliminar a Islas: 
Si lo sagrado es el tiempo de los orígenes, suerte de prehistoria, o historia ancestral, tiempo entonces poético por excelencia, como ella misma precisa en otra ocasión, toda su experiencia cubana y puertorriqueña (pero sobre todo aquella primera, por su relación con la Poesía) son, para María Zambrano, el símbolo carnal, viviente, físico, encarnado, del mundo de lo sagrado. En primer lugar, porque ella lo sintió así, quiero decir, no creo que haya ninguna realidad exenta de esa presencia, pero era lo que ella buscaba entonces, si bien es cierto que su contacto con un imaginario otro tuvo que favorecer ese encuentro, ese descendimiento, esa revelación (Islas XXIII).

Por una parte, ciertamente Zambrano se encuentra en Cuba con el medio poético y literario que es urdido alrededor de la revista Orígenes, escenario donde desarrollará amistades y descubrirá proximidades espirituales e intelectuales. Mas, por otra, la filósofa tiene la oportunidad de conocer la singular cultura de las islas, con todo lo premoderno que en ella subsiste, puntualmente una relación viva entre el hombre y lo divino dominada por un politeísmo sincrético afín, como Arcos apunta, "a las religiones y mitos grecolatinos, tan caros a María" (Islas XXIV). Se trata, específicamente el de la isla de Cuba, de un ámbito que Zambrano ensalzará en cuanto "mundo mágico en que la 'realidad' no está delimitada, y aún el sueño puede igualar a la vigilia" (Islas 118), el lugar más propicio como para constituirse en "patria inextinguible de la metamorfosis" (Islas 118) y desde donde hacer partir la senda órfico-pitagórica, que se revelará como ruta de regreso a lo primordial. Corrobora Miguel Morey:

María Zambrano tiene treinta y seis años, y más de un pasado detrás. Ha estado, está, están los suyos muy cerca de la muerte, demasiado cerca. Ahora enfrente está Cuba [...]. Allí, Zambrano se siente arropada, arrullada quizá por vez primera, desde hace mucho tiempo. La fraternidad de Lezama y de las gentes de Orígenes, la magia amable pero profunda de La Habana, de toda Cuba, donde del Caldero de Oggún renacen sin descanso los orishas, las siete potencias del panteón yoruba y bantú, los dioses africanos de las religiones del Monte doblados sin la menor violencia sobre el santoral católico: Obatalá (el dios de la concordia, Nuestra Señora de las Mercedes), Elegguá (el mensajero, el Santo Ángel Guardián), Orunmila (el dueño de la Tabla de Ifá sobre la que pronostican los babalaos, San Francisco de Asís), Changó (El Gran Putas y señor del rayo, Santa Bárbara), Oggún (el dios del hierro y la guerra, San Pedro), Yemayá (la diosa del mar de los yorubas, la Virgen de la Regla), y Oshún (la coqueta diosa del amor, la Virgen de la Caridad del Cobre, patrona de la Isla de Cuba)... ¿Puede extrañarnos así que, en el seno de este barroco sincretismo, M. Zambrano se encontrara cara a cara con Orfeo, el dios que marcó las cadencias del remo de los Argonautas, el cantor que hechizó a las potencias del infierno para rescatar de sus catacumbas a la ninfa Eurídice? (105). 
El orfismo-pitagorismo, entonces, se revela, en Zambrano, como solo la reliquia más próxima de lo olvidado, lo perdido y lo arcaico, en cuanto originario. Si la filósofa avanza en su senda intentando recuperar sus elementos clave, es porque el norte hacia el que se orienta su cardus, vislumbrado en el Caribe mágico y religioso, es, en verdad, el más radical 'antes' que pueda imaginarse; un 'antes' prehistórico en el más estricto sentido de la palabra. Un 'antes' edénico.

\section{Hacia una consciencia prehistórica}

Determina a este 'antes' una total ausencia de búsqueda; no hay todavía pérdida alguna que exija reposición. Cuando la haya, será la rememoración o el intento restaurativo de la plenitud quebrantada lo que, para Zambrano, vendrá a caracterizar el inicio de los tiempos históricos. Indicador de esta falta de necesidad es la primordial y absoluta independencia de la olvidada palabra originaria respecto del posterior lenguaje, asociado ya a la vocación de indagar y constituido como una nueva forma de saber que, inexorablemente, devendrá propiedad y dominio:

Antes de los tiempos conocidos, antes de que se alzaran las cordilleras de los tiempos históricos, hubo de extenderse un tiempo de plenitud que no daba lugar a la historia. Y si la vida no iba a dar a la historia, la palabra no iría tampoco a dar al lenguaje, a los ríos del lenguaje por fuerza ya diversos y aun divergentes. Antes de que el género humano comenzara su expansión sobre las tierras para luego ir en busca siempre de una tierra prometida, rememoración y reconstitución siempre precaria del lugar de plenitud perdido, las tierras buscadas, soñadas, reveladas como prometidas venían a ser engendradoras de historia, inicios de la cadena de una nueva historia. Antes. Antes, cuando las palabras no se proferían proyectadas desde la oquedad del que las lanza al espacio lleno o vacío de afuera; al exterior. Y así el que profería, el que ha seguido profiriendo sus palabras, las hace de una parte suyas, suyas y no de otros, suyas solamente, entendiendo o dando por entendido que quienes las reciben quedarán sometidos sin más. Ya que el exterior es el lugar de la gleba, de lo humano amorfo, materia dispuesta para ser conformada, configurada, y a la que se pide que siga así, gleba bajo la única voluntad de quien profiere las palabras materializadas también, ellas también materialización de un poder (Claros del bosque 193).

Quizá esté de más aclarar que este es el deber que mueve a Zambrano en su estricto rol de filósofa: rescatar a la palabra de la miseria a la que la ha llevado su progresiva instrumentalización, no sin antes denunciar su apoderamiento por parte de la alineación racionalista de Occidente. Como asevera Virginia Trueba en su introducción a La tumba de Antígona (26): "Denuncia, pues de la cautividad, desgaste, inflación de 
la palabra en un mundo que la ha condenado a la pura servidumbre en manos de los poderosos, o al mero canje de la comunicación ordinaria”.

Es para cumplir este propósito de rescate que Zambrano plantea, rotundamente, la necesidad de volver al "fondo de los tiempos" hasta reencontrar la fuente misma de la palabra, en el soterrado estrato anímico de la especie: "Habrá que hacer a derechas lo que tan perversamente se hizo. Es decir: habrá que rescatar muchas cosas del alma humana que la orgullosa fe en el progreso dejó atrás; habrá que sacar del fondo de los tiempos, no a los ídolos sino a las almas, a las creencias, a los saberes sepultados por la prisa y la vanidad del hombre occidental" (Algunos lugares de la poesía 76).

El "fondo de los tiempos", lo tempranísimo, entonces, es aquello que interesa a nuestra filósofa; lo que en su condición de recién naciente se encuentra en la frontera entre el ser y el no ser que antecede. Por esto, aquella especie de noción suprema de la filosofía zambraniana que es la Aurora: el tenue albor que media entre la noche y el amanecer. Entre las múltiples proyecciones que tal noción adquiere en la madurez de Zambrano, está precisamente la de una "era de la Aurora", que es la de las culturas primitivas o, mejor aún, primordiales u originarias. "Ocultadas" por los tiempos históricos en su progreso racional, los testimonios de esta era resultarán cada vez más incomprensibles, apenas pudiendo el arte "rememorar" su sentido en contadas y especialísimas oportunidades:

Y el círculo de piedras miliares de Stonehenge, llevadas allí desde inmensas distancias cuando rueda no había, depositadas armoniosamente, tales notas musicales con entidad propia y en inmarcesible relación. Sólo ellas mismas podrían hablar de su origen y contar, y quizá mejor cantar, su función [...].

Podría ser que las piedras cantasen naturalmente de por sí, lo que sólo después, en momentos especialmente luminosos del arte y de la tradición se da, según muestra el descubrimiento de Marius Schneider en su estudio sobre la función de los animales símbolos que ornan los capiteles de los claustros de Santa María de Ripoll y de San Cugat del Vallés [...]. ¿No será lo que el arte más agudamente logre, el rememorar lo que en la Era de Aurora sucedía? Y así la ocultación de esa Era, su caída, su inmersión en el tiempo cada día más histórico y menos historiable, ha dejado como ininteligibles sus huellas en sutiles manifestaciones (De la Aurora 169-170).

La anterior cita evidencia el interés de Zambrano por las cosmovisiones primitivas. Y, por cierto, también evidencia cómo este interés se nutre de los estudios musicológicos y etnográficos de Marius Schneider, cuyos descubrimientos y postulados remontan precisamente a los primeros albores de la consciencia humana, todavía semiidentificada con el universo animal. Escribe Schneider respecto del "sistema" que supone reconstruir en El origen musical de los animales-símbolos (1946):

Dada la posición histórica de los instrumentos musicales y de la ideología perteneciente a ellos, podemos asegurar que la cristalización definitiva del sistema 
se concluyó en el segundo milenario a. de C., pero sus raíces se pierden en la obscuridad de los milenarios precedentes. Su base, el realismo en la imitación de los ritmos animales, es claramente pretotemística y sus primeras etapas evolutivas están determinadas por un totemismo de cazadores (375).

Los parentescos entre la música y la aurora humana se vuelven evidentes a la luz de Schneider. Luego, si a Zambrano le interesa el pitagorismo es porque este viene a ser el último vestigio de un auroral saber músico, el que justamente deberá afrontar la definitiva marginación y obnubilación a manos del saber filosófico cuando comience a ser sistematizado. Diferencia Schneider las civilizaciones desarrolladas de las culturas primitivas atendiendo a sus respectivas formas de representación, para destacar la musicalidad radicalmente prelógica de los antiguos en su tan inmediata como inconsciente identificación con la realidad; ciertamente, la "era de la Aurora" se hunde en los tiempos que, muy remotamente, anteceden al pitagorismo:

La concepción primitiva de lo esencial es realista, artística e intuitiva; su carácter dinámico: en las altas culturas la concepción de la última realidad es geométrica, científica y abstracta. Para ella la última verdad se verifica sólo en el reposo (y no en el movimiento), en las formas o ideas puras y en los números-ideas, mientras que las formas accidentales o fluctuantes sólo son exteriorizaciones imperfectas de las ideas. Al paso que las altas civilizaciones "piensan" y sistematizan conscientemente sus ideas por medio de una serie de signos abstractos (símbolos), los primitivos "bailan" y cantan sus ideas, que en su mayoría viven en las capas inferiores de la conciencia (Schneider 20).

Zambrano avanza en su obra, diríase, intentando desandar la historia de Occidente en su condición de proyecto epistemológico, encaminándose hacia las alógicas bases del pitagorismo, y más allá. Queda de manifiesto que el 'norte' señalado por la música a Zambrano tiene que ver con la "conciencia en estado virginal" (La tumba de Antígona 240), la propia aurora humana, desvanecida u "ocultada" en su inocencia por la progresiva clarté del devenir filosófico. Es sobre este remoto paradigma que Zambrano terminará cuestionando radicalmente la concepción de "consciencia" que históricamente ha operado en Occidente, reidentificando la palabra con el más primordial -virginal-sentir, del todo reverente tanto de lo oculto como de las insondables complejidades del tiempo. Aclara la filósofa en La experiencia de la historia (Después de entonces), el texto escrito en La Pièce durante 1977 -contemporáneo a Claros del bosque, o sea ya plenamente recorrida la senda órfico-pitagórica-, que a partir de entonces figurará como introducción a Los intelectuales en el drama de España:

Mas para que la experiencia histórica se dé como indispensable en este Occidente, habría de entenderse -de sentirse ante todo- la conciencia en forma diferente de la dada por sabida. Es decir, que la primera experiencia que habría de surgir es la del ejercicio de la conciencia misma. Pues que hasta ahora la conciencia 
suele deslizarse por un tiempo plano, allanador de sucesos, desconocedor de la multiplicidad que el tiempo despliega en la vida humana. Es necesario que deje intacta la semilla de vida germinante siempre visible o escondidamente, que respete lo escondido y no pretenda imponer la claridad -la racionalista "clarté"- que tantas realidades luminosas oculta (Los intelectuales en el drama de España 79-80).

La pregunta insoslayable, empero, es si acaso es posible un retorno tal, o sea, si efectivamente se puede retroceder o trascender la historia hasta recuperar la consciencia primigenia. Mas, cabe recordar aquí que dos son las historias que distingue la filósofa: la auténtica y la "apócrifa", aquella que "asfixia casi constantemente a la verdadera" y de la que, con pesadumbre, reconocerá que no por apócrifa es "menos cierta" ( $\mathrm{La}$ tumba de Antígona 154). Recurriendo a las interpretaciones simbólicas de Guénon en Le Symbolisme de la Croix (1931), Zambrano relacionará respectivamente ambas historias, la auténtica y la apócrifa, con la cruz y el aspa, que es cruz deformada por el trastorno de su eje vertical, representativo de la relación entre la Tierra y el Cielo. Negada esta primordial relación, queda solo la mera aspa, la rueda del progreso, la que interesa "a los servidores del poder para hacerla girar a su conveniencia", según manifiesta Virginia Trueba (La tumba de Antígona 86-87). Es en ella, como asegura Zambrano, también en La experiencia de la historia, donde es crucificado el inocente: "Y así el inocente se vino a encontrar crucificado en el aspa de la historia, en la rueda movida por fuerzas contrarias, que deben proceder de un centro que se despierta sin cesar, una y otra vez, y que pide sacrificio humano" (Los intelectuales en el drama de España 84).

Y, por cierto, donde -siempre en la encrucijada de las fuerzas contrarias que mueven la historia apócrifa- es crucificada la inocencia misma, la de los inocentes que han muerto matando, pues, "la inocencia sólo llega a matar muriendo, muriéndose" (Los intelectuales en el drama de España 82). Tal es la paloma -que Zambrano asimila al Espíritu Santo-, avasallada en y por los hombres:

¿Habrá perdón para el que estrangula una paloma?

Amor. Paloma crucificada. ¿No hemos crucificado los hombres todavía al Espíritu Santo? Ella padece de su herida, mana su sangre, la sangre del amor herido, la del amor inútilmente manchado, paloma inaccesible a toda humillación y humillada, aquí, por nosotros (O.C. VI 1068).

Ante la pregunta, entonces, de si acaso es posible desandar la historia apócrifa, la historia sacrificial, y retornar a la aurora en el intento de recobrar la primitiva y perdida inocencia, es que comparece en todo su esplendor la invaluable riqueza de María Zambrano en cuanto filósofa y persona: en que son los alcances de su propio proyecto, y siempre en cuanto fiel correlato de su propia vida, los que parecen confirmar la auténtica posibilidad de una recuperación tal. Ciertamente se trata, la de Zambrano, 
de una obra esencialmente testimonial, donde la trascendencia de la historia no es teoría sino experiencia. Y arranca esta del padecimiento sacrificial mismo, misteriosamente aconteciendo el anhelado retorno a la aurora precisamente en la ocultación más ominosa, que en el caso de Zambrano adquiere la fisonomía concreta del exilio, tan largo como denso en desventura.

\section{Antígona o la aurora en la tumba}

La gran figura de este proceso, en la obra zambraniana, es Antígona, símbolo de la "aurora de la conciencia" (La tumba de Antígona 152). La escritura que esta heroína originará en Zambrano posee, según nuestra lectura, el doble valor de ejemplificar acabadamente una pasión trascendente de la historia sacrificial y de constituir un primer gran cipo en la senda de regreso, acaso el correspondiente al hallazgo del cardinal rastro músico en el asumido trance de delirar. Efectivamente, es con Delirio de Antígona (1948) que Zambrano inicia una profundización en el género 'delirio', preparando el terreno para la maduración del carácter oral-aural-musical de su discurso. Para nosotros, resulta incuestionable que tal impronta se encuentra implícita en el solo concepto de delirio, dada su clara vinculación con la arcaica manía música. Del todo concordante con este antecedente, el delirio, en Zambrano, suele poner en relevancia una 'voz' (la de Cordelia, Antígona, Diótima, Ofelia, Ana de Carabantes y, por cierto, la de la misma Zambrano), la que en su calidad de voz es que "puede ser oída" (La tumba de Antígona 173). Es esta oralidad-auralidad, o, más derechamente, musicalidad primordial, la que, inaugurada con los delirios, alcanzará su plenitud en Claros de bosque, el hito decisivo de la senda anímico-musical recorrida por Zambrano.

El recurso heteronímico, que caracteriza a una parte importante de los delirios zambranianos, se concentra repetidas veces en la voz de la condenada hija de Edipo, a la que Zambrano identifica expresamente con su hermana Araceli (O.C. VI 1060), mujer del perseguido republicano Manuel Muñoz y, por eso, víctima ella misma de la Gestapo. Mas, partiendo de esta identificación, Zambrano hace arrancar de Antígona toda una "estirpe" de seres, elevándola como junguianamente a la condición de "arquetipo" (La tumba de Antígona 167). Tal estirpe es la de "los enmurados" (168), aquellos que, damnificados por la ocultación, trascienden su propia desgracia calificándolos tal trascendencia como "no solamente vivos, sino vivientes" (168). Por esto es que, a diferencia de Sófocles, Zambrano, en La tumba de Antígona, no solo trueca el fin suicida de la heroína, sino que transfigura su espantosa condena en oportunidad para la experiencia. La ocultación, que en Antígona es ni más ni menos que su entierro viva -descenso obligado a las catacumbas-, devela su condición de tiempo, experimentable hasta la muerte, la que, para los enmurados -a diferencia de otros- se devela como paso a la eternidad: 
Pues que la muerte oculta a ciertos "seres" cuando les llega, y revela a otros revelando la vida inextinguible: en la historia y más allá, en un horizonte sin término. Un trascender revelador al que es preferible llamar tránsito, cuya imagen más fiel es el adormirse.

La ocultación se produce de otra manera en esta clase de seres -personajes y excepcionalmente humanas criaturas-: una tumba cuando se les da y un tiempo de olvido, de ausencia como en el sueño. Con este olvido se les da tiempo. El tiempo que se les debe, que coincide con el tiempo que los humanos necesitan para recibir esa revelación, claros que se abren en el bosque de la historia ( $a$ tumba de Antígona 165-166).

Mermados espacio y luz, queda el enmurado a solas y a oscuras con el tiempo. Y es entonces que puede experimentarlo. Pues el castigo infringido por el poder es privar de los bienes que él mismo ha impuesto, mas sin sospechar que castigando abre una puerta precisamente a lo que ha marginado y escondido, que en la Antígona zambraniana viene a ser el tiempo abismal, oscuro y fugitivo, otro radical respecto del espacio delimitado, iluminado e inmóvil donde se afinca y desarrolla "la creencia racionalista en que el mundo está compuesto de cosas, no de acontecimientos; de sustancias y no de sucesos; en que el mundo es estático, fundamentalmente idéntico a sí mismo" (Los intelectuales en el drama de España 89). Explica Zambrano en El hombre y lo divino:

Es comprensible que el espacio haya tenido la primacía en atraer al pensamiento, en ser buscado como "el lugar del ser", identificado con él. Pues el espacio lleva consigo la salida a la luz. El hombre que siente haber ganado en espacio siente al par que sale a la luz; la cárcel es siempre oscura. Y el primer sentir que el hombre debió tener cuando se dio cuenta de que estaba solo, solo y rodeado de algo inaccesible, debió ser, sin duda, el sentirse en una caverna. La Alegoría de la caverna platónica arrastra esta vivencia. Salir al espacio se confundirá con "salir a la luz" (85).

Y confronta de inmediato el paradigma localizador, diurno y lógico de la naciente filosofía con el temporal, nocturno y músico aún vigente en el orfismo-pitagorismo: "Mientras que la representación nacida del sentir del tiempo será nocturna y abismal. Y si la palabra corresponde a la luz -el logos-luz-, el abismo de la noche temporal se hará accesible al manifestarse en la música, forma del tiempo" (El hombre y lo divino 85).

Así padecida la ocultación, como sea y donde sea que fuese, puede volverse, entonces, una experiencia de alcances místicos, sostenido el enmurado por una consolación misteriosa que lo aproxima a los incógnitos órdenes de una aurora que, aún ocultada, 'renace' en cada encarnación de la Antígona arquetípica:

En lugares señalados o en medio de la ciudad entre los hombres indiferentes, dentro de una muerte parcial, que les deja un tiempo, que los envuelve en una especie de gruta que se puede esconder en un prado o en un jardín, donde se 
les ofrece un fruto puro y un agua viva que les sostiene ocultamente: sueño, cárcel a veces, silencios impenetrables, enfermedad, enajenación. Muertes aparentes. Lugares reales y, al par, modos con que la conciencia elude y alude, se conduce ante estas criaturas. Y ellas se ocultan y reaparecen según números desconocidos. Vuelven en una aparición que progresa al modo de la aurora ( $\mathrm{La}$ tumba de Antígona 168).

La referencia a los místicos en cuanto "apariciones" del arquetipo, o seres investidos de la "vocación Antígona" (La tumba de Antígona 170), es irrecusable. Asoma, entonces, en su presidio toledano, Juan de la Cruz y su fe no "como adhesión a contenidos temáticos construidos a partir de la analogía entre Dios y el mundo y entre Dios y el hombre", sino "como itinerario a través de la 'experiencia', hacia lo Incognoscible" (Rossi 130). Informa Gerald Brenan:

Durante los dos primeros meses de su reclusión estuvo encerrado en una celda prisión ordinaria del convento, pero al saberse que su compañero en la Encarnación, fray Germán de San Matías, había logrado escapar de la casa donde estaba confinado, fray Juan fue trasladado a un lugar mucho más seguro. Éste consistía en una pequeña habitación de seis por diez pies que servía de retrete a la habitación de huéspedes adjunta. Estaba iluminada por una aspillera de tres dedos de ancho situada en la parte superior de la pared, de modo que para leer los oficios tenía que subirse al banco y levantar el libro hacia la luz, y aun así tan sólo podían distinguirse las letras al mediodía (45-46).

Empero, y de acuerdo al relato de Brenan, tras seis meses de encierro, fray Juan recibe pluma y tinta de manos de un carcelero más piadoso. Viene el éxtasis una tarde, tras la audición de música, puntualmente un villancico callejero ("Muérome de amores, Carillo. ¿Qué haré? -Que te mueras, alahé"), dando pie para la composición, al menos preliminar, del Cántico espiritual. Por esto es que, a la pregunta de Ana de San Alberto, sobre si había recibido divino consuelo en aquella mazmorra, años más tarde, el carmelita responderá: "Hija Ana, una sola gracia de las que Dios allí me concedió no podría pagarse ni con muchos años de cárcel” (cit. en Brenan 48).

La aurora zambraniana, renacida en cada ser tomado por la "vocación Antígona", se devela, entonces, como figura de la virginidad de la consciencia, estado no forzado por la "violencia filosófica" (Filosofía y poesía 17) que la autora denuncia en Filosofía y poesía (1939). Retornar a la aurora equivale así a volver a una "conciencia en estado naciente" (La tumba de Antígona 170), próxima al zambraniano "sentir originario", aquel que Luis Rosa Invernón explica en cuanto, del hombre, "su sentirse originado y su sentir el origen" (64). Sentir de la criatura primordial que subyace, tan oculto como inviolado, en la memoria de las-los Antígonas:

Simplicidad, pureza, nitidez sellan a estas figuras haciéndolas recognoscibles. Lo que en ellas se afirma y resplandece es su condición de criatura -figuras, 
palabras del primer Poema; memoria despierta del "Fiat Lux", al que se les ha dado responder con el "Fiat mihi" de la criatura primera, sin que ellas siempre lo sepan-. Criaturas virginales de larga vida, pues que cuando se les acorta, se les da un tiempo propio, inalienable (La tumba de Antígona 169).

Mas, este retorno a la aurora obnubilada, o su recuperación, obedece a "una suerte de catarsis trágica o de alquimia" (Laurenzi 18). Se trata de la "purificación radical” que Rossi (130) ha observado, precisamente, en la experiencial fe como "noche" que, en cuanto "preludio al amor", opera como característica de la mística de Juan de la Cruz; un proceso de 'purificación de la consciencia' que tiene lugar en la memoria, a solas con el tiempo dado en la sacrificial ocultación, purgando a la consciencia del puro 'yo' que ha venido a tapar el resto de la realidad, luego, conduciendo a una suerte de estado que recuerda el edénico, previo a la 'caída' que trae consigo la separación entre el sujeto y el mundo. Describiendo a su heroína, escribe Zambrano:

Símbolo perfecto de la virginidad que ni siquiera ha reparado en sí misma. Misterio de la virginidad en toda la plenitud; y por ello, de la conciencia en estado virginal. La conciencia virgen alumbra y se dirige a lo que no es ella misma, a lo que no es tampoco el sujeto a quien pertenece. Raro momento de perfección humana, pues el hombre sale de su sueño para entrar en la conciencia a través de una falta, de un crimen. Conciencia es despertar del ensueño de la vida; pues vivir debe ser originalmente permanecer hundido en el sueño sin saber alguno acerca de las diferencias entre las cosas; diferencia que se da sobre la primera, aquella abismal entre nosotros y la realidad que nos rodea.

Y una vez que los humanos despiertan de su ensueño a la conciencia, inmediatamente vuelven a la luz que ella arroja, sobre sí mismos, caen en la cuenta de sí y lo que nombramos yo toma cuerpo y lo que es peor, peso. Y así, nuestro propio ser viene a interferirse en la luz, destello de la luz original que es la conciencia. Y se pierde la conciencia pura, original (La tumba de Antígona 240).

\section{El tiempo sacrificial vuelto música}

El de Antígona, empero, no es un sacrificio cruento. Radica aquí una importante causa de porqué Zambrano ha elegido a este personaje y no a otra condenada como para comunicar el sentido tanto sacrificial como soteriológico de la ocultación; no hay en Antígona holocausto, el que ha sido sustituido, no obstante, por una equivalente 'entrega al tiempo':

Vida y conciencia inocentes, intactas. Y así, hubo de bajar entre los muertos, viva. El terrible castigo le era también adecuado; sólo el fuego que consume podía haberlo suplantado, consumiéndola como a otra doncella perfecta: Juana de Arco. Para la perfecta virginidad del alma y de la conciencia, sólo tienen los 
hombres preparada una celda donde se consume lentamente, o una hoguera, fuego que se lleva para sí lo que en realidad le pertenece (La tumba de Antígona 241).

Se emparenta la equivalencia acusada por Zambrano a aquella transformación sacrificial que, en la historia de las religiones, viene, poco a poco, a incorporar la noción del sacrificio sutil. Ya presente en las exigencias de la himnología védica, se lee implícita y acaso cristalizada, para las inmediaciones de Occidente, precisamente en la conducta órfica que tanto interesa a nuestra filósofa; Guthrie (68) recuerda cómo para Platón el orfismo distingue a los hombres según su abstinencia de la carne, mencionando que para los órficos era impío mancillar los altares con sangre, consideración que Aristófanes extenderá al solo hecho de derramarla. Por su parte, Claudio Naranjo, recordando la tradición hinduista aún en su fase primitiva, señala lo que para nosotros resulta clave: "La antigua religión védica, al inicio de la corriente espiritual hindú, giraba en torno al fuego y el sacrificio a través del fuego, símbolo ceremonial de que aquello que se sacrifica se transforma en el fuego mismo. Sacri-facere, hacer sagrado o sacrificar, es en este caso no solo entregar algo a la no-existencia, sino a una transformación" (Naranjo 192).

Transformación que comenzará a ser no solo sutil, sino interior: "Hubo un momento en la historia de las religiones en que el sacrificio externo se transformó en un sacrificio interiorizado [...] en la India el sacrificio del fuego -el sacrificio védico que significaba devolver el mundo de la multiplicidad a la unidad, el mundo manifiesto a lo inmanifiesto, el ser individual a su origen divino- se transformó en acto psicológico" (Naranjo 192).

Una rápida reflexión en torno al rol de entidad transformadora, "que se lleva para sílo que en realidad le pertenece" (La tumba de Antígona 241), y que es el desempeñado por el fuego en el sacrificio antiguo, nos pone en la pista de la música como el sutilísimo elemento que, en su temporalidad ontológica, viene a sustituirlo. Efectivamente, la consideración de la música o lo musical como figura de máxima transformación y valor en el proceso sacrificial, luego estrictamente solidario de lo sagrado, ya se observa en la misma ritualidad cruenta. Apelamos nuevamente a Schneider: "Todo lo que vale procede de un sacrificio. El caballo, el reno o el ciervo tienen que sacrificar su piel (que San Agustín consideraba como símbolo de la mortalidad) para llegar a ser tambor, esto es, en la visión védica y chamanística, 'jefe’ o 'carro místico'. Por la misma razón se fabricaban tambores con cráneos humanos” (204).

Y, ciertamente, el tiempo sacrificial que Antígona experimenta o padece en su tumba, y que es el que la transforma, es un tiempo que adquiere calidad de música, por ella y en ella. Un aspecto de esta musicalidad, el 'sonoro', aparece caracterizado en cuanto primitivísimo, según lo signado por Zambrano cuando menciona los "gemidos" y los "delirios" (La tumba de Antígona 241) de la víctima. Pues, como aclara la filósofa en El hombre y lo divino (83), el "gemido" remite a la "angustia del tiempo", aquella que "inspiró el orfismo", explicando luego cómo “[1]a música órfica es el gemi- 
do que se resuelve en armonía" y aclarando que "el gemido no es queja desesperada, imprecación, sino dulzura secreta, misteriosa dulzura que sale de las entrañas del infierno" (El hombre y lo divino 109). Por su parte, la mención del "delirio", como ya señaláramos, cursa al más arcaico sentido de lo músico, cuyo clásico testimonio es el ofrecido por Sócrates en el Ion: la extática y privativa expresión del vate durante su enthousiasmos, según Fubini, el factor aédico sobre el cual "nunca se ha dudado ni se ha discutido entre los críticos" (39). Y, ante todo, siempre de la mano con esta primitiva significancia música, el delirio se erige en Zambrano como figura no tanto de lo irracional como de lo prerracional, que es el ámbito al que lo auroral se asoma y del que participa. En palabras de Morey, a propósito de los delirios zambranianos escritos durante el exilio caribeño: "Ahora, en La Habana, el delirio será el precipitado literario, la forma que abre la posibilidad de someter el ordo geometrico de la razón a las exigencias de la experiencia poética, la propia de un alma empeñada en sostenerse sobre el gesto de renacer, como un ángel del dintel: el delirio, 'la prehistoria de la razón, su alba'. Canto" (108).

Efectivamente, para la filósofa, el delirio es lo primigeniamente humano, lo único posible de surgir ante la noche órfica, en un momento que antecede a cualquier denominación, cuando todavía no hay ni lenguaje, ni espacio, ni cosas, ni dioses; solo ignorancia inocentemente esperanzada ante una presencia tan absoluta y omnisciente como oscura y angustiante en su innombrabilidad. Establece Zambrano en El hombre y lo divino (29): "Pues en el principio era el delirio; el delirio visionario del Caos y de la ciega noche. La realidad agobia y no se sabe su nombre". E insiste más adelante:

En el principio era el delirio; quiere decir que el hombre se sentía mirado sin ver. Que tal es el comienzo del delirio persecutorio: la presencia inexorable de una estancia superior a nuestra vida que encubre la realidad y que no nos es visible. Es sentirse mirado no pudiendo ver a quien nos mira. Y así, en lugar de ser fuente de luz, esa mirada es sombra. Mas, como en todos los delirios humanos, la esperanza está presente, y más quizá que en ninguno, por ser el primero. La esperanza está prisionera en el terror; la angustia de sentirse mirado envuelve la apetencia de serlo, y toda la apetencia que se despierta, que acude ante esa presencia que se manifiesta ocultándose (31).

Pero esta faceta 'sonora' del tiempo musical experimentado por Antígona en su tumba, cede ante la otra, la sanjuánica "música callada", no determinada por la voluntad de la heroína, sino subyacente en el estrato más íntimo e inaudito de la realidad, solo asequible mediante la escucha en su más extremo ejercicio. "Cuánto rumor en el silencio, noche, cuánta vida en mi muerte" (La tumba de Antígona 178), reconocerá Antígona una vez rendida ante el tiempo, re-signando el valor de su encierro en una experiencia auditiva de claras resonancias schneiderianas, la que hace del sepulcro una puerta auroral: 
No, tumba mía, no voy a golpearte. No voy a estrellar contra ti mi cabeza. No me arrojaré sobre ti como si fueras tú la culpable. Una cuna eres; un nido. Mi casa. Y sé que te abrirás. Y mientras tanto, quizá me dejes oír tu música, porque en las piedras blancas hay siempre una canción. Quise oírla siempre, la voz de la piedra, la voz y el eco, esos dos hermanos que son la voz y el eco; hermana y hermano, sí. Mas las humanas voces no me dejan oírlas. Porque no escuchan, los hombres. A ellos, lo que menos les gusta hacer es eso: escuchar. Pero yo, mientras muero, quiero oírte a ti, mi tumba, quiero oíros a vosotras, piedras de esta tumba mía blanca como la boca del alba ( $\mathrm{La}$ tumba de Antígona 178).

\section{La última frontera}

La condición de "nido" o de "cuna" que Antígona adjudica a su tumba, evidencia la sensibilidad de Zambrano respecto de los elementos que integran lo que Durand ha designado como "régimen nocturno de la imagen", constituido, primeramente, por los llamados "símbolos de la inversión". Destaca aquí, precisamente, la conversión órfica del espanto mediante una acción musical cuya inefabilidad reemplaza la función categorizadora del lenguaje:

El mordisqueo se eufemiza en engullimiento, la caída se frena en descenso más o menos voluptuoso, el gigante solar se ve mezquinamente reducido al papel de pulgarcito, el pájaro y el vuelo son reemplazados por el pez y el encastre. La amenaza de las tinieblas se invierte en noche benefactora, mientras que colores y tinturas reemplazan la pura luz; y el ruido, domesticado por Orfeo, el héroe nocturno, se transmuta en melodía y viene a suplantar, mediante lo indecible, la distinción del habla y las palabras (Durand 242-243).

El valor de la noche en cuanto terrible, se invierte, entonces, hasta llegar al propio de "la Stille Nacht, la 'Santa', el lugar del gran reposo" (Durand 225), las tinieblas 'santificadas' cuyo paradigma se halla, una vez más, en la poesía de Juan de la Cruz, donde, según Durand, "la noche se convierte en el sitio privilegiado de la incomprensible comunión" (226). Así es que la Noche Oscura, para el místico carmelita, es "amable más que el alborada" (Juan de la Cruz 44) tal como para Zambrano su exilio es objeto de amor, ciertamente incomprensible para aquel que no lo ha experimentado, descubierta en la ocultación tanto su absoluta inexorabilidad como el sentido del sacrificio que viene a diferenciar la historia verdadera de la apócrifa, hundida en la insensatez. Señala Zambrano en Amo mi exilio (1989):

Creo que el exilio es una dimensión esencial de la vida humana, pero al decirlo me quemo los labios, porque yo querría que no volviese a haber exiliados, sino que todos fueran seres humanos y a la par cósmicos, que no se conociera el 
exilio. Es una contradicción, qué le voy a hacer; amo mi exilio, será porque no lo busqué, porque no fui persiguiéndolo [...].

Mi exilio está plenamente aceptado, pero yo, al mismo tiempo, no le pido ni le deseo a ningún joven que lo entienda, porque para entenderlo tendría que padecerlo, y yo no puedo desear a nadie que sea crucificado (Las palabras del regreso 66-67).

Pues sin noche no hay aurora, enraizada esta en la oscuridad que antecede, la que, para Zambrano, refiere nuevamente a la prehistoria de la consciencia, empero, en su fase más remota:

En mi exilio, como en todos los exilios de verdad, hay algo sacro, algo inefable, el tiempo y las circunstancias en que me ha tocado vivir y a lo que no puedo renunciar. Salimos del presente para caer en el futuro desconocido, pero, sin olvidar el pasado, nuestra alma está cruzada por sedimentos de siglos, son más grandes las raíces que las ramas que ven la luz. Es en la obra del amanecer, trágica y de aurora, en que las sombras de la noche comienzan a mostrar su sentido y las figuras inciertas comienzan a desvelarse ante la luz, la hora de la luz en que se congregan pasado y porvenir (Las palabras del regreso 67).

Tal radical prehistoria posee un indudable carácter 'prenatal', lo que confirma, en su inversión, el símbolo de la tumba. De hecho, Durand denomina, justamente, como "complejo de retorno a la madre" (244) al instinto responsable del proceso de inversión simbólica que acaba, isomórfica y eufemísticamente, asimilando el sepulcro no solo a la cuna, como menciona Zambrano, sino al vientre materno. Es en esa instancia prenatal donde la filósofa ubica al olvidado germen de la historia verdadera, tal como dispone en el prólogo a los textos recopilados en Senderos (1986):

Los hechos de la historia que, lejos de ocultar, dejan transparentarse a la vida, acaban arrojando su sentido muy tarde, es decir, cuando ya no hay remedio, cuando no se podría dar un paso atrás, ni tan siquiera en sueños; es lo que diferencia a la verdadera historia, es decir, la inexorable, la que lo ha movido todo desde el principio de la vida, de aquellos a quienes visita o a quienes elige. Todo parece estar ordenado por ella desde un comienzo, me atrevería a decir que en ciertos casos, desde antes de haber nacido individualmente. La verdadera historia, de aquellos que la tengan, es en verdad prenatal, y para no inculpar a los padres inmediatos, diríamos mejor y más justamente, ancestral (8).

Se trata, empero, de una prehistoria que es incognoscible en términos conscientes; Zambrano apela a la memoria, mas, a sabiendas de la frontera infranqueable que a la consciencia le impone el olvido:

Los recuerdos se hundían entonces en la primera infancia, en un fondo oscuro, fluido, de donde luchaban por aparecer. Pero entonces, y siempre el recuerdo; la 
memoria aparece como viniendo de un olvido, de un oscuro fondo que ofrece una resistencia inexpugnable. Y somos así, opacos a nosotros mismos en esa primera, espontánea forma de conocimiento en que ni siquiera pretendemos conocernos, que es la memoria (O.C. VI 851).

Sin embargo -y he aquí la proximidad entre Zambrano y la psicología analítica-, está el universo inconsciente, la oscuridad de las entrañas o los infiernos del ser, posible de ser conocidos, o 'sabidos', en los sueños o en ese soñar a medias que son los delirios. Luego, si Zambrano llamó a Cuba su "patria pre-natal” (Islas 92), constituyendo su experiencia caribeña el antecedente vivo de la senda "órfico-pitagórica", es porque en tal experiencia lo que parece haber comparecido es una versión más íntegra de la realidad, en la que "el sueño puede igualar a la vigilia" (Islas 118), o sea, donde las fronteras entre ambos cabos están ostensiblemente desdibujadas. Y tal es lo que ocurre en el delirio, primera manifestación música, medio cubierta, irremediablemente, por la oscuridad de la inconsciencia que precede a la "tragedia inicial de haber nacido" (O.C. VI 848).

\section{A modo de conclusión: Dionisio y la insatisfacción de la consciencia}

Si la figura de la noche es símbolo del reverso de la clarté de la consciencia, la aurora, entonces, lo es de la sutilísima intersección entre el ser que aquella ilumina y lo que Bachelard ha llamado su "antecedencia”, cognoscible no 'mediante' sino 'en' la ensoñación poética:

Cuando los poetas nos llaman hacia esa región, entramos en un ensueño tierno, en un ensueño hipnotizado por lo lejano. Llamamos a esta tensión de las ensoñaciones de infancia, no teniendo otro nombre mejor, antecedencia del ser. Para entreverla hay que aprovechar la destemporalización de los estados de gran ensoñación. Creemos que así se pueden conocer estados que están ontológicamente por debajo del ser y por encima de la nada (Bachelard 168).

Análogamente, en Zambrano, esta realidad prenatal comparece en el delirio mismo y como en un estado de pura presencia; en un 'por nacer' que nunca llega a realizarse, o que, si llega a hacerlo, cede ante la inmediata arremetida de la muerte, la que remite de vuelta a la oscuridad, imponiendo el renacer. Se trata de la experiencia que, mal naciendo, nunca podrá cristalizarse en un 'algo' -una razón, una sustancia- que satisfaga a la consciencia. Nos encontramos, entonces, en la madura Zambrano de Claros del bosque, con un gesto definitivamente órfico: posicionar la musical figura de Dionisio y su mítica dificultad para nacer en cuanto símbolo de la experiencia que, mal naciendo al mundo de la consciencia, solo puede saberse dionisiacamente. 
Regalados de una comunicación de la vigilia con el sueño, o de la vida con la muerte que la precede y a la que retorna, los posesos por este dios no saben mediante acabadas razones sino en el mismo delirio músico manifiesto en la danza y en el canto; saber inasible y gratuito que se pierde en el tiempo pues a él pertenece, nunca llegando a una cristalizadora definición, sino apenas participando brevemente del tenue albor de la aurora que al mismo tiempo lo devela y lo desvanece:

Dios de incompleto nacimiento, del padecer y de la alegría, anuncia el delirio inacabable, la vida que muere para volver de nuevo. Es el dios que nace y el dios que vuelve. Embriaga y no sólo por el jugo de la vid, su símbolo sobre todos, sino ante todo por sí mismo. La comunicación es su don. Y antes de que ese su don se establezca hay que ser poseído por él, esencia que se transfunde en un mínimo de sustancia y aun sin ella, por la danza, por la mímica, de la que nace el teatro; por la representación que no es invención, ni pretende suplir a verdad alguna; por la representación de lo que es y que sólo así se da a conocer, no en conceptos, sino en presencia y figura; en máscara que es historia. Signo del ser que se da en historia. La pasión de la vida que irremediablemente se vierte y se sobrepasa en historia. Y que se embebe sólo en la muerte. El dios que se derrama, que se vierte siempre, aun cuando en los "Ditirambos" se dé en palabras. Las palabras de estos sus himnos siguen teniendo grito, llanto y risa al ser expresión incontenible. Expresión que se derrama generosa y avasalladoramente (Claros del bosque 154).

El proyecto zambraniano se metarritmiza en el recorrido de su cardus, el que parece conducir a la frontera extrema de la consciencia, cuyo impenetrable 'más allá solo puede ser sabido en cuanto sentido, danzado, cantado, delirado, empero jamás cabalmente argumentado o explicado. Mas, ¿adónde es que efectivamente llega Zambrano en su senda? ¿Cambian significativamente, acaso, los grandes contenidos de su proyecto -sus problemas, sus amores- con la ruta recorrida? Ciertamente no. ${ }^{1}$ ¿En qué consiste, entonces, la metarritmisis de su discurso? Ateniéndose a lo que sucede en él, puede asegurarse que Zambrano alcanza la musicalidad de sus palabras. Es este un hecho irrefutable; basta leerla en voz alta, basta oírla como para comprobarlo. Luego, podría decirse, sin mayores aprehensiones, que la música en Zambrano señala un norte que viene a ser ella misma. Si efectivamente esto es así, o sea, si en Zambrano la música conduce a y coincide con la fragilísima o evanescente consciencia auroral,

1 Corrobora Mercedes Gómez Blesa: "No está de más advertir que el pensamiento zambraniano presenta una morfología bastante unitaria: no se observan en él grandes fallas que separen claramente una etapa de otra, ni tampoco se vislumbran grandes giros de su pensamiento que indiquen una revolución interna de su filosofía. Nada de esto se contempla cuando se analiza la obra de Zambrano, sino más bien lo contrario, esto es, el seguimiento de un mismo camino, de un continuum, trazado desde sus inicios, con sus primeras colaboraciones periodísticas del año 28, en las que ya deja sentadas sus principales preocupaciones filosóficas, que serán desarrolladas en cada uno de sus escritos hasta su última obra póstuma, Los sueños y el tiempo" (Zambrano, Las palabras del regreso 27-28). 
participando de su más allá, ¿cabrá siquiera la posibilidad de considerar en cuanto 'música', lo que Zambrano menciona como la "ley" "de las resistencias y apetencias últimas", el "desnudo palpitar en la obscuridad” (Islas 93), en fin, todo cuanto se extiende tanto allende como aquende los dominios de la consciencia, el reino de las cabales determinaciones, de los nombres y las categorías, incluida - por cierto- la de lo nominalmente 'humano'? Tal es la alucinante posibilidad que, nos parece, Zambrano ha dejado abierta.

\section{Referencias}

Arcos, Jorge Luis. "María Zambrano y la Cuba secreta". Ensayo cubano del siglo XX. Antología. Eds. Rafael Hernández y Rafael Rojas. México, D. F., FCE, 2002, pp. 638-657.

Bachelard, Gastón. La poética de la ensoñación. Trad. Ida Vitale. México, D. F., FCE, 2014.

Balza, Isabel. "Los vacíos de un texto: hacia la razón poética de María Zambrano". Cuadernos del Ateneo, n. ${ }^{\circ} 32,2014$, pp. 40-54.

Brenan, Gerald. San Juan de la Cruz. Trad. Jaume Reig. Barcelona, Plaza \& Janés, 2000.

Durand, Gilbert. Las estructuras antropológicas de lo imaginario. Trad. Víctor Goldstein. México, D. F., FCE, 2004.

Fubini, Enrico. La estética musical desde la Antigüedad hasta el siglo XX. Trad. Carlos Pérez de Aranda. Madrid, Alianza, 1999.

Guthrie, William Keith Chambers. Orfeo y la religión griega. Estudio sobre el "movimiento órfico". Trad. Juan Valmard. Madrid, Siruela, 2003.

Laurenzi, Elena. "María Zambrano, filósofa de la Aurora". Aurora. Papeles del "Seminario María Zambrano”, n. 3 3, 2001, pp. 16-24.

Moreno Sanz, Jesús. El logos oscuro: tragedia, mística y filosofía en María Zambrano, vol. I. Madrid, Verbum, 2008.

Morey, Miguel. "Delirios en La Habana. Materiales de lectura". Aurora. Papeles del "Seminario María Zambrano", n. 2, 1999, pp. 103-113.

Naranjo, Claudio. "Música y conciencia”. La música como proceso humano. Coord. Patxi del Campo. Salamanca, Amarú, 1997, pp. 185-206.

Platón. Diálogos, vol. I. Trad. Julio Calonge, Emilio Lledó y Carlos García. Madrid, Gredos, 1985.

Rosa Invernón, Luis. "El tiempo como desgarramiento en el pensamiento de María Zambrano". Persona. Revista Iberoamericana de Personalismo Comunitario, n. ${ }^{\circ} 11,2009$, pp. 62-67.

Rossi, Rosa. Juan de la Cruz. Silencio y creatividad. Madrid, Trotta, 2010.

San Juan de la Cruz. Poesías completas. Madrid, Aguilar, 1959.

Schneider, Marius. El origen musical de los animales-símbolos en la mitología y la escultura antiguas. Madrid, Siruela, 2010. 
Unamuno, Miguel de. Obras completas, vol. VIII. Madrid, Biblioteca Castro, 2007. Zambrano, María. El hombre y lo divino. México, D. F., FCE, 2016.

---. La tumba de Antígona y otros textos sobre el personaje trágico. Ed. Virginia Trueba. Madrid, Cátedra, 2015.

---. Claros del bosque. Madrid, Cátedra, 2014.

---. Obras completas, vol. VI. Barcelona, Galaxia Gutemberg, 2014.

---. Filosofía y poesía. México, D. F., FCE, 2013.

---. Notas de un método. Madrid, Tecnos, 2011.

---. Las palabras del regreso. Ed. Mercedes Gómez Blesa. Madrid, Cátedra, 2009.

---. Algunos lugares de la poesía. Madrid, Trotta, 2007.

---. Islas. Ed. Jorge Luis Arcos. Madrid, Verbum, 2007.

---. De la Aurora. Madrid, Tabla Rasa, 2004.

---. La razón en la sombra. Antología crítica. Ed. Jesús Moreno Sanz. Madrid, Siruela, 2004, pp. 75-79.

---. Los intelectuales en el drama de España y escritos de la guerra civil. Madrid, Trotta, 1998.

---. Senderos. Barcelona, Anthropos, 1986.

Recibido: 24 enero 2018 Aceptado: 13 septiembre 2018 